\title{
Use of pedological maps in the identification of sensitivity of soils to acidic deposition: application to Brazilian soils
}

\author{
ADOLPHO J. MELFI ${ }^{1 *}$, CELIA R. MONTES ${ }^{1}$, ADILSON CARVALHO ${ }^{2}$ \\ and MARIA CRISTINA FORTI ${ }^{3}$ \\ ${ }^{1}$ Departamento de Solos e Nutrição de Plantas, Escola Superior de Agricultura Luiz de Queiroz \\ Universidade de São Paulo and Núcleo de Pesquisa em Geoquímica e Geofísica da Litosfera, NUPEGEL \\ Cx. Postal 09, 13418-900 Piracicaba, Brasil \\ ${ }^{2}$ Departamento de Sedimentologia e Geologia Ambiental, Instituto de Geociências \\ Universidade de São Paulo and NUPEGEL \\ ${ }^{3}$ Instituto Nacional de Pesquisas Espaciais and NUPEGEL, 12201-970 São José dos Campos, Brasil
}

Manuscript received on March 6, 2003; accepted for publication on October 1, 2003; contributed by ADOLPHO J. MELF**

\begin{abstract}
The pedogeochemical maps present the spatial distribution of soils according to crystalochemical parameters (clay fraction) and physic-chemical aspects of the sorting complex (CEC and BS). These maps are adequate tool for environmental studies and particularly, for the analysis of the terrestrial ecosystem sensibility to acidic deposition. The pedogeochemical maps of the Brazilian soils, elaborated using FAO Soil World Map, allowed establishing the soil distribution according to 5 classes of vulnerability to acidic deposition, as defined by Stockholm Environmental Institute (SEI). From these maps, it is observed that about 50\% of the Brazilian soils are high vulnerable to acidic deposition and can be included within the most sensitive class. This group is formed by well-developed and mature soils, constituted by clay minerals of kaolinite type associated with variable amount of gibbsite. About $8 \%$ of the soils can be considered as the least sensitive class. They correspond to Topomorphic Vertisols (Vertissolo, Embrapa 1999), Planosols (Planossolo, Embrapa 1999) and saline soils. Finally, the remaining soils represent the balanced media that dominate the northeastern semiarid zones and the south and northeastern subtropical zones.
\end{abstract}

Key words: Brazilian soils, pedogeochemical map, soil buffering ability.

\section{INTRODUCTION}

The acidic deposition in the earth surface has been studied all over the world, particularly in the North hemisphere, where the most important industrialized regions are located. In the South hemisphere the studies, despite their large number, are very limited, considering both the geographical and time aspects.

* Member of Academia Brasileira de Ciências

Correspondence to: Adolpho J. Melfi

E-mail: ajmelfi@usp.br
Anyhow, it is known that the acidic deposition can induce important changes in the terrestrial ecosystem with hazardous effect for the human being and vegetation. These effects are related with the acid rain characteristics and also with some other parameters, including climate, vegetation and particularly soil.

The soil, the most important constituent of the continental biosphere, can be highly affected by the acidic deposition. As a consequence, important changes can occur in the physicochemical charac- 
teristic of the sorting complex, affecting directly the soil productivity and the filtering capacity as well.

The most important physicochemical characteristics are base saturation (BS) and cation exchange capacity (CEC). These characteristics, associated with the clay fraction nature, were used in France by Pédro and Scherer (1974) to build up the so-called pedogeochemical maps, which were applied, later on in Brazil, by Melfi and Pédro (1977, 1978). This type of map is an adequate tool for environmental studies and in particular, for the analysis of the terrestrial ecosystems sensitivity to acidic deposition.

In this paper, by using modern techniques of digital cartography, different thematic maps were obtained and the classes of vulnerability to acidic deposition were defined for the Brazilian soils, according to Cinderby et al. (1998).

\section{MATERIALS AND METHODS}

\section{Methodological Basement}

The methodology applied in this study is based on the geochemical interpretation of pedological maps, developed by Pédro and Scherer (1974). It was shown that the mechanisms concerned with the superficial geochemical alteration and soil formation are related to crystalochemical, hydrodynamic and physicochemical parameters. The crystalochemical parameter refers to the nature of the secondary constituents (clay minerals), and the hydrodynamic parameter refers to water saturation status (hydromorphy and orthomorphy). On the other hand, the physicochemical parameter defines the major mechanisms of superficial evolution (alcalinolysis, acidolysis, hydrolysis and salinolysis).

As considering the case of the Brazilian territory, it was observed (Melfi and Pédro 1978), that the most important mechanism is the hydrolysis, which includes the majority of the soils ( $>97 \%$ ), followed by acidolysis $(>2 \%)$. As concerning the hydrodynamic parameter, it was also shown that only about $10 \%$ of the soils are included in the hydromorphic class and the rest belongs to the orthomophic class.
Based on these results and using the FAO World Soil Map (FAO/UNESCO 1971) Melfi and Pédro (1978) produced a map of the Brazilian territory showing the geographical distribution of the mechanisms of superficial alteration.

\section{Method of Study}

The map showing the distribution of the soils sensitivity to acidic deposition is elaborated following the method of Cinderby et al. (1998). This method is based essentially in the soils buffering capacity that depends on two soil characteristics concerning the sorting complex state: Base Saturation (BS) and Cation Exchange Capacity (CEC).

Base saturation (BS) is used to indicate the soil weathering rate: the higher the weathering rate, higher the base saturation. But, high base saturation can also indicates an accumulation due to soil processes other than weathering. In any case, base saturation is used to assess the soil buffering properties and three ranges of base saturation were selected: $0-35 \%, 35-80 \%$ and $80-100 \%$.

Cation exchange capacity (CEC) can modify the soil sensitivity defined by the base saturation. The presence of a high CEC has an effect of dampening the $\mathrm{pH}$ fluctuations caused by acidic deposition. Thus, soils having a given base saturation would have a lowered sensitivity with high CEC compared to soils with moderate CEC. For mapping purpose, three categories of CEC were proposed: $<10,10-25$ and $>25 \mathrm{cmol}_{\mathrm{C}} / \mathrm{kg}$ soil.

In the present study, the geographical distribution of the crystalochemical and physicochemical parameters of the sorting complex were obtained from the analysis of a digital version of the South America Soil Map (FAO/UNESCO 1992) using the computational program Arc View GIS, 3.1. These maps were used to elaborate the soil vulnerability map to the acidic deposition

\section{THE BRAZILIAN SOILS}

The Brazilian Territory is situated nearly entirely within the intertropical zone of the Globe and conse- 
quently, is covered by a pedological mantle formed essentially by well-developed, strongly weathered and deep soils. These soils present strongly desaturated sorting complex and are constituted by clay minerals of low reactivity. They include the Ferralsols (Latossolo, Embrapa 1999), Acrisols (Latossolo Ácrico, Embrapa 1999) and Arenosols (Neossolo Quartzarênico, Embrapa 1999) of FAO/UNESCO (1971) classification, covering $80 \%$ of the Brazilian Territory.

\section{Characterization of Soils Sorting Complex}

\section{Mineralogical constitution}

The clay minerals and Al/Fe oxide-hydroxides are the dominating secondary constituents of the Brazilian territory. Considering only the siliceousaluminous compounds (clay minerals), the Brazilian soils can be grouped into three types of pedological cover. Two of them, kaolinitic (monosialitic) cover and smectitic (bisialitic) cover, present high alteration degree of the parent material (100\%), whereas in the third one, mixed sialitic (mono and bisialitic) cover, the alteration degree does not reach $100 \%$.

- The kaolinitic cover presents a sorting complex formed essentially by kaolinite, associated with a major or minor amount of gibbsite. Oxides and hydroxides of iron (goethite and hematite) are always present.

- The smectitic cover is constituted, essentially by 2:1 clay mineral types, associated with minor amounts of kaolinite and iron oxides/hydroxides.

- The mixed sialitic cover presents mainly kaolinite, together with illite, vermiculite or chlorite. More rarely, kaolinite is replaced by smectite.

Figure 1 shows the distribution of the different pedological covers.

The kaolinitic cover is the most important domain, covering about $55 \%$ of the Brazilian territory and includes all the Ferralsols, Nitosols (Nitossolo, Embrapa 1999) and Arenosols. It is distributed all over the Brazilian territory, from the equator down to $35^{\circ} \mathrm{S}$ latitude. Gibbsite is mainly abundant within the basaltic zone of Paraná basin, the Central plateau zone and Amazon region.

The smectitic cover is distributed in three distinct zones: (i) Northeast, characterized by a warm and slight arid climate, with the dominance of Luvisols (Luvissolo, Embrapa 1999); (ii) Pantanal, a depressed and hydromorphic zone, dominated by Planosols and (iii) Lower area of Cuesta de Huedo, in the northern part of the basalt lava flow in Paraná basin, under subtropical climate with alternate dry season, dominated by Vertisols.

Finally, the mixed sialitic cover corresponds to the area of Acrisols, well developed, leached soils formed on acid rocks.

\section{Physicochemical characterization}

The evolution of the sorting complex is well characterized by means of the its base saturation rate (BS) which is defined as the ratio of the total bases ( $\mathrm{S}$ ) and cation exchange capacity (CEC) (BS $=$ S/CEC $\times 100$ ).

\section{Cation Exchange Capacity of the BraZILIAN SOILS (CEC)}

Considering that the clay fraction composition is dominated by 1:1 clay mineral (kaolinite) associated or not with gibbsite and the low content of organic matter, the Brazilian soils present, in general, a rather low cation exchange capacity. The figure 2 shows the geographical distribution of the Brazilian soils according to CEC values. It can be observed that nearly $55 \%$ presents $\mathrm{CEC}<10 \mathrm{cmol}_{\mathrm{C}} / \mathrm{kg}$ and include all the Ferralsols, the Arenosols and part of the Acrisols. Soils having CEC ranging from 10 to $25 \mathrm{cmol}_{\mathrm{C}} / \mathrm{kg}$ occur in Amazon region, alongside the great rivers, in the semi-arid Northeast and in Pantanal, covering an area of about $42 \%$. The remaining (about 3\%) present CEC $>25 \mathrm{cmol}_{\mathrm{c}} / \mathrm{kg}$ and correspond to small areas of Vertisols in the extreme south of the country and of saline soils in the northern coast of Amapá, Pará and Maranhão States. 


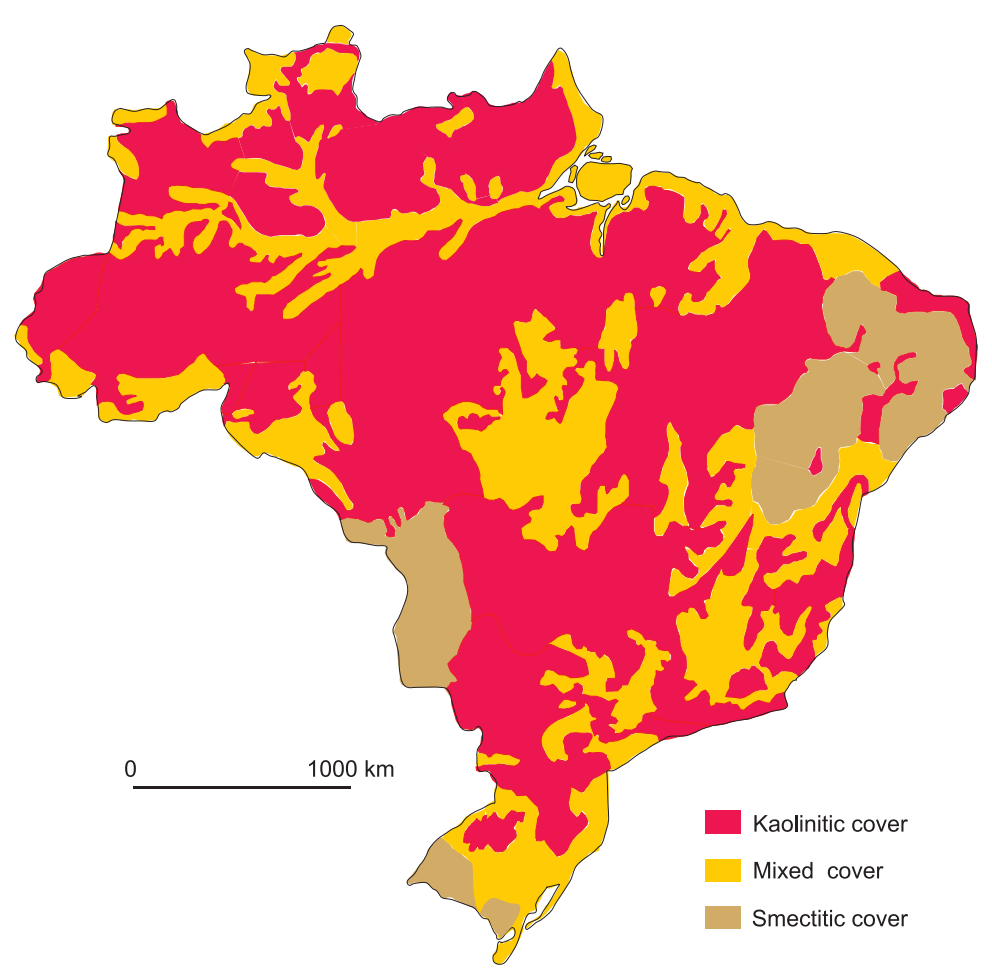

Fig. 1 - Distribution of different pedological covers in Brazil.

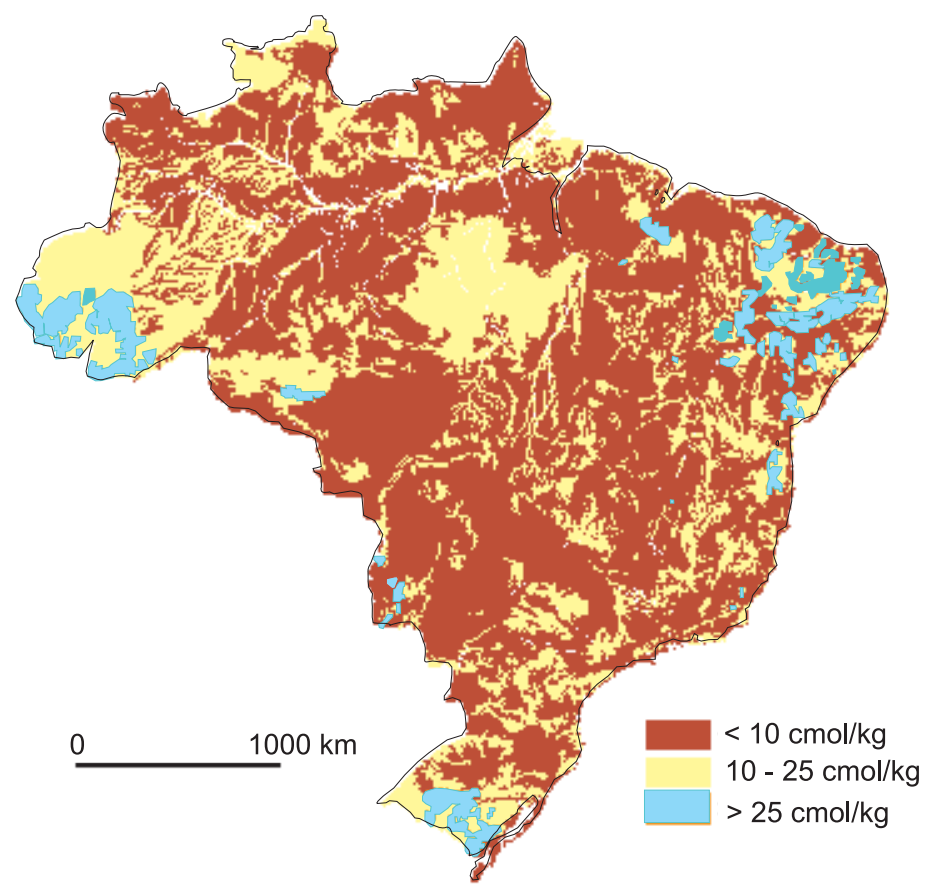

Fig. 2 - Distribution of cation exchange capacity $\left(\mathrm{CEC}\right.$ in $\mathrm{cmol}_{\mathrm{C}} / \mathrm{kg}$ ) values in Brazil. 


\section{Base Saturation Rates (BS)}

The Brazilian pedological cover is essentially formed by leached soils and consequently, a sorting complex with low base saturation would be expected. Actually, $>80 \%$ of the soils have BS values $<35 \%$ and therefore are considered as strongly desaturated. All the Ferralsols, Acrisols, Arenosols and the Dystric Gleysols, Regosols and Nitosols are included in this category. The other category refers to soils having BS values between 35 and $80 \%$, which are considered as slightly desaturated and represent about $15 \%$ of the Brazilian soils. It includes the Luvisols of the semi-arid Northeast, the Planosols of Pantanal and also the Eutric Regosols (Neossolo Regolítico, Embrapa 1999) and Mollic Gleysols (Gleissolo, Embrapa 1999). The soils representing equilibrated medium, having a sorting complex with BS values $>80 \%$ are restrict in Brazil, not exceeding 7\%. This category includes the saline soils in the northern coast, the Vertisols in the extreme south and the Phaeozens in the high cold regions in the south of the country (Figure 3).

\section{DISCUSSION}

By using the maps of distribution of cation exchange capacity and base saturation it was possible to build up a map with the distribution of classes of vulnerability of Brazilian soil to acidic deposition (Figure 4).

In figure 4 it can be observed that the soils presenting higher sensibility to acidic deposition (classes 1 and 2) are distributed all over the country, covering about $80 \%$ of its surface, dominating the regions under humid or sub-humid tropical climates. About $55 \%$ of these soils, having CEC lower than $10 \mathrm{cmol}_{\mathrm{c}} / \mathrm{kg}$ and $\mathrm{BS}$ lower than $35 \%$, are high vulnerable to acidic deposition and can be included within the most sensitive class. This group is formed by well-developed and mature soils, mostly Ferralsols, Arenosols and part of the Acrisols; constituted by clay minerals of kaolinite type associated with variable amount of gibbsite. They appear as continuous areas in the most part of the Amazon region, of Central Brazil and Brazilian southeast.
Nearly $8 \%$ of the Brazilian soils, having variable values of CEC and high BS (> 80\%), are included within the less sensible soils (classes 4 and 5), presenting a higher buffer capacity to acidic deposition. They correspond to Topomorphic Vertisols, Planosols and saline soils.

Finally, the remaining soils present BS varying from 35 to $80 \%$ and variable CEC ( $>10 \mathrm{cmol}_{\mathrm{c}} / \mathrm{kg}$ ). They represent the balanced media that dominate the regions with a dryer and contrasted climate (semiarid northeast) and also occur in certain depressed zones, where the bisialitization pedological process is easier developed (e.g. coastal saline zones, Pantanal and depressed zones of the extreme south Pampas).

\section{RESUMO}

Os mapas pedogeoquímicos representam a distribuição espacial dos solos de acordo com seus parâmetros cristaloquímicos (fração argila) e dos aspectos físico-químicos de seu complexo absorvente (Capacidade de troca catiônica CEC e saturação em bases - BS). Esses mapas constituem excelentes ferramentas para os estudos ambientais e, em especial para a análise da vulnerabilidade de ecossistemas terrestres à deposição ácida. Os mapas pedogeoquímicos dos solos brasileiros, obtidos a partir da análise do Mapa Mundial de Solos da FAO, permitiram estabelecer a distribuição dos solos em 5 classes de vulnerabilidade à deposição ácida, conforme normas definidas pelo Stockolm Environmental Institute (SEI). Nesses mapas pode ser observado que cerca de $50 \%$ dos solos brasileiros são altamente vulneráveis à deposição ácida e podem ser incluídos na classe dos solos de vulnerabilidade mais elevada. Este grupo é formado pelos solos dessaturados, bem desenvolvidos, constituídos por argilominerais do grupo da caolinita, associados a quantidades variáveis de gibbsita. Cerca de $8 \%$ dos solos podem ser considerados como pertencentes à classe de menor vulnerabilidade. Eles correspondem aos Vertissolos, Planossolos e solos salinos. Finalmente, os solos remanescentes representam os solos das zonas semi-árida do nordeste e subtropical do sul do nordeste.

Palavras-chave: solos brasileiros, mapa pedogeoquímico, poder tampão de solos. 


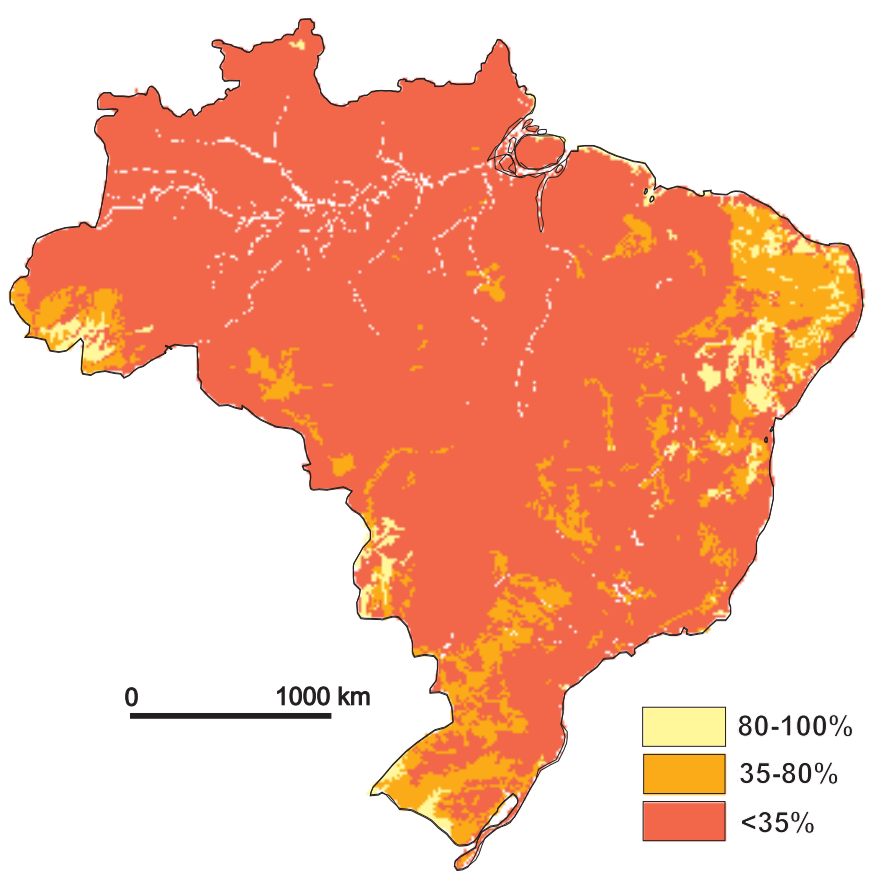

Fig. 3 - Distribution of base saturation (BS) values in Brazil.

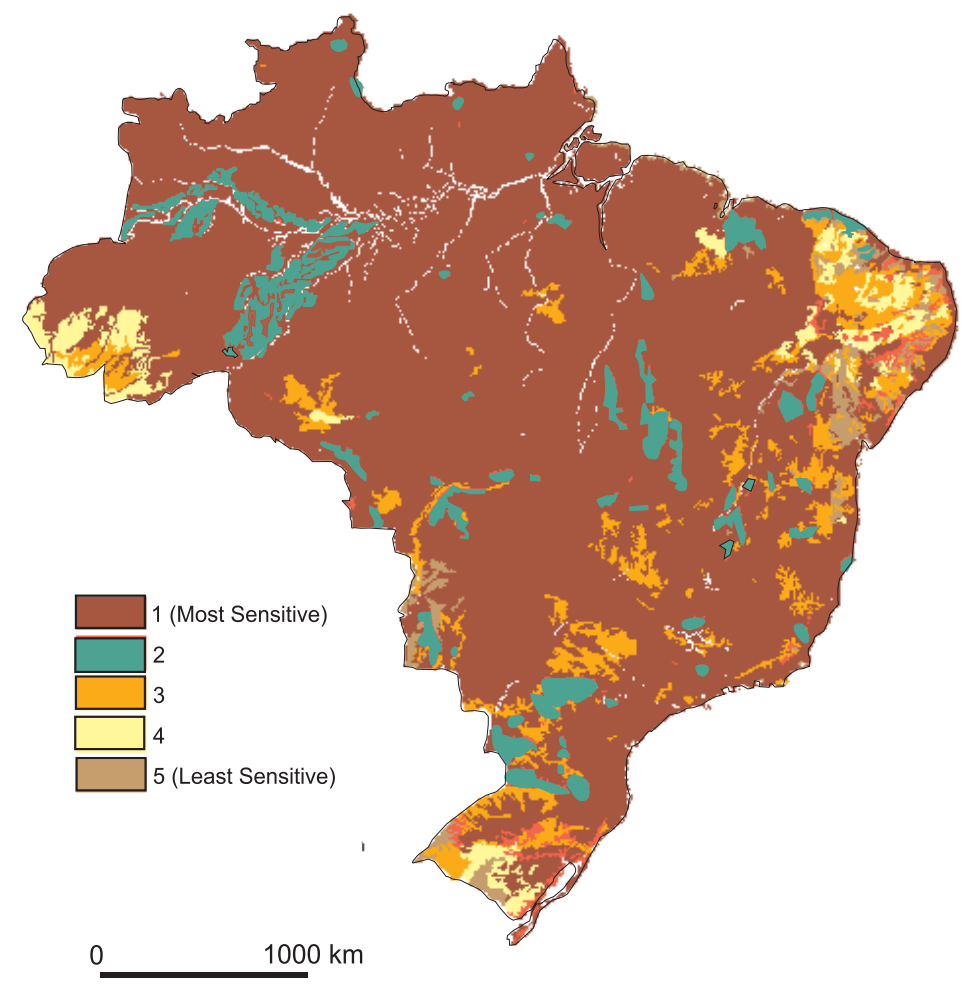

Fig. 4 - Distribution of ecosystem sensitivy to acidic deposition in Brazil. 


\section{REFERENCES}

Cinderby S, Cambridge HM, Herrera R, Hicks WK, Kuylenstirna JCI, Murray F and Olbrich K. 1998. Global assessment of ecosystem sensitivity to acidic deposition, Stockholm Environment Institute, Stockholm, $20 \mathrm{p}$.

EMBRAPA. 1999. Sistema brasileiro de classificação de solos. Embrapa Solos, 412p.

FAO/UNESCO. 1971. Soil Map of the World, Volume IV - South America, UNESCO, Paris.

FAO/UNESCO. 1992. Digital Soil Map of the World, UNESCO, Paris.
Melfi AJ AND Pédro G. 1977. Estudo geoquímico dos solos e formações superficiais do Brasil. Parte 1: Caracterização e repartição dos principais tipos de evolução pedogeoquímica. Rev Bras Geoc 7: 271-276.

Melfi AJ AND PÉdro G. 1978. Estudo geoquímico dos solos e formações superficiais do Brasil. Parte 2: Considerações sobre os mecanismos geoquímicos envolvidos na alteração superficial e sua repartição no Brasil. Rev Bras Geoc 8: 11-22.

PÉDro G AND SCHERER S. 1974. Essai d'interpretation geochimique de la carte pedologique de France. Ann Agron 25: 25-48. 